\title{
Livelihood improvement of poor farmers through goat rearing in Mymensingh district of Bangladesh
}

\author{
Hossain $\mathrm{MM}^{*}$, MK Alam and M Haque
}

Department of Animal Science, Bangladesh Agricultural University, Mymensingh- 2202, Bangladesh

\begin{abstract}
The study aimed to examine the feeding, management, income and livelihood improvement through goat rearing in Mymensingh district. The study was conducted at different unions namely Gazirvita, Koichapur and Norail of Haluaghat Upazila in Mymensingh district. Total 45 respondents were randomly selected from three unions where 15 from each union. The respondents were classified into three distinct groups. The farmers belonged to Group-G, who lives in Gazirvita union, Group-K, who lives in Koichapur union and Group-N, belonged to the farmers who lives in Norail union. The period of data collection was from April to June, 2011. The farmer's families were poorest of the poor and illiterate. The annual total cost of production of Black Bengal goat was Tk. 2154, while gross return and net return per household were Tk. 4296 and Tk. 2142, respectively. Educational status, employment for men, employment for women, social dignity and social acceptance were increased at 35, 24, 58, 26 and $23 \%$ through goat rearing in the study area. The result clearly indicates that livelihood increases dramatically through goat rearing in the study area.
\end{abstract}

Key words: poor farmers, goat rearing, livelihood improvement

Bangladesh Animal Husbandry Association. All rights reserved.

Bang. J. Anim. Sci. 2017. 46 (1): 29-34

\section{Introduction}

Goats have significant contribution in GDP through production of meat, milk and skin representing about $27.0,23.0$ and $28.0 \%$, respectively to the total production from livestock sector (FAO, 2009). Goat is economically suited for the poor people. Goat requires less feed than cattle. They are usually maintained on tree leaves, shrubs and bushes in the rural condition. Because of the docile nature and small size they are easy to handle and are preferred by the rural women as a domestic animal to keep.

In Bangladesh, about $45 \%$ of the people live below the poverty line (BBS, 2014). About 36\% of the total farm households of Bangladesh are involved in rearing goat under scavenging condition (BBS, 2007). It has an important role as national income also important for creating employment opportunities (Huq et. al., 1990), savings and income generation of the poor people. Poor people can earn a lot of money and improve their standard of living by goat rearing. Government and Non-Government Organizations (NGOs) are providing micro credit and necessary training to the rural farmers to increase the production of goat in Bangladesh. The government of Bangladesh has started a national programme in 2002 (Islam and Huque, 2002) on poverty alleviation, self employment, food supply and increase of skin exportation through goat rearing. There are five government goat development farms in different regions of Bangladesh to supply progeny (buck, doe and kid) and technologies to the rural goat farmers.

So far, a few works have been done about the livelihood change of poor rural farmers by goat rearing in Bangladesh. But goat has significant importance on livelihood improvement. So, the work has been done to measure the livelihood changes of goat keepers. Taking this point into consideration, the present experiment was carried out to investigate the socio-economic status, income and livelihood changes of goat keepers in Haluaghat Upazila of Mymensingh, Bangladesh. The study was conducted to investigate the following objectives:

i) To know the feeding, management and income generation of goat rearing.

ii) To estimate the livelihood changes of goat farmers.

\section{*Corresponding author: mmh_bau2009@yahoo.com}




\section{Goat farming for poor farmers}

\section{Materials and Methods}

\section{Study area}

The location of the experiment was rural areas of different unions of Haluaghat upazila in Mymensingh district of Bangladesh. Haluaghat Upazila is located at $55 \mathrm{~km}$ north of Mymensingh town. It is located at the adjacent to Indian border with Meghalaya where plenty of pasture land is available. Therefore, this area is very much suitable for goat rearing to livelihood improvement of the poor farmers.

\section{Selection of respondents}

Fifteen respondents were randomly chosen from each union. Therefore, in total 45 respondents were chosen from three unions for collection of data to satisfy the objectives. The respondents were classified into three distinct groups according to the first letter of their union name. The farmers were belonged to Group-G, who live in Gazirvita union, Group-K belonged to the farmers who live in Koichapur union. Group-N belonged to the farmers who live in Norail union. Distributions of respondent are shown in Table 1.

Table 1. Name of the district, upazila, union and number of farmers in experimental area

\begin{tabular}{|c|c|c|c|c|}
\hline District & $\begin{array}{c}\text { Upazil } \\
\text { a }\end{array}$ & $\begin{array}{c}\text { Unio } \\
\mathbf{n}\end{array}$ & Village & $\begin{array}{l}\text { Number } \\
\text { of farmers }\end{array}$ \\
\hline \multirow[t]{3}{*}{$\begin{array}{l}\text { Myme } \\
\text { nsing } \\
h\end{array}$} & $\begin{array}{l}\text { Halua } \\
\text { ghat }\end{array}$ & Gazirvita & $\begin{array}{l}\text { Dumnikur } \\
\text { a } \\
\text { Nolkura } \\
\text { Bhalkakur } \\
\text { a }\end{array}$ & 15 \\
\hline & & Koichapur & $\begin{array}{l}\text { Palashtala } \\
\text { Chotodasp } \\
\text { ara } \\
\text { Borodaspa } \\
\text { ra }\end{array}$ & 15 \\
\hline & & Norail & $\begin{array}{l}\text { Bagmara } \\
\text { Itakhola } \\
\text { Khorma }\end{array}$ & 15 \\
\hline 01 & 01 & 03 & 09 & 45 \\
\hline
\end{tabular}

\section{Preparation of the interview schedule}

The interview schedule was carefully prepared based on the objectives of the study. A draft schedule was developed before preparing the final schedule. The draft schedule was then pretested with selected farmers in the study area and then it was rearranged and modified as required. The schedule was developed so simple manner to avoid misunderstanding and to get accurate answer. Eventually it was finalized according to the experience gathered in the preliminary field survey. This helped the respondents to understand the interview schedule easily and furnish the required information swiftly and systemically.

\section{Procedure of data collection}

The researcher collected the information through personal interview from the individual respondent present in their own house. An introductory visit was made to the study area when the aims and objects of the study were explained to most of the respondents. This helped to have a friendly orientation of the respondents. Brief information regarding the nature and purpose of the study was made to the respondents before actual interview. The researchers also established desire rapport with respondents. Questions were asked systemically and explained whenever it was felt necessary. The information supplied by the respondents was recorded directly on the interview schedule. The information was checked carefully before leaving the study area in order to minimize errors. Data were collected in local unit. These were subsequently converted into appropriate standard unit. The respondents were interviewed at their own house so they could give accurate information without any hesitation and sound mind. No serious problem was faced by the respondents during data collection. Excellent cooperation was received from all respondents at the time of data collection period. Data were collected during April to June, 2011.

\section{Tabulation of the data}

After completion of field survey all the interview schedules were set for its data tabulation for coding and reduction. All the individual variables of the interview schedules were transferred to master sheet to facilitate tabulation. Tabulation as well as cross tabulation were done on the group basis.

\section{Daily routine activities of farmers for goat rearing}

Goats were taken outside the house at 6.00 to $6.30 \mathrm{am}$. Then the houses were cleaned. The goats were supplied with drinking water and some supplements at 6.30 to $7.00 \mathrm{am}$. The goats 
were then taken in the field or roadside for grazing. The goats were grazed there until 5.00 or $6.00 \mathrm{pm}$. At $12.00 \mathrm{am}$ to $1.00 \mathrm{pm}$ the farmers gave rest to the goats under the tree in the yard or outside and supplied drinking water. The goats were then returned to the house and supplied with drinking water. At $6.00 \mathrm{pm}$ goats were sheltered in house.

\section{Statistical analysis}

Various statistical measures like number, mean, percentage distribution, Chi-square test were done to describe the variables.

\section{Results}

\section{Socio-economic information of the farmer in Haluaghat Upazila}

The socio-economic information of the farmers in Haluaghat Upazila included population of livestock keeping by the farmers, educational status and the occupational status of the farmers. Most of the farmers lived in tin shed and katcha house. Most of the farmers also reared poultry with goat. The average age of the farmers ranged from 32 to 50 years and they had a minimum or no land for cultivation. Table 2 presents the educational level and occupational status of the farmers. It was revealed that most of the farmers showed almost the similar record about the literacy status.

Main feeds and major sources of feed for goat in experimental area

Main feeds and major sources of feed for goat in experimental area are presented in the Table 3. It is found that most of the ingredients were mixed (own + roadside) and also bought during the scarcity period.

\section{Disease and health care of goats}

In the study area, there was a serious lack of prevention and treatment facilities and goats are found very much susceptible to various contagious diseases. Two major diseases of goat were found there. These were skin disease and Peste des petits ruminants (PPR). Table 4 shows that major disease of goat in experimental area was skin disease (73.3\%) and PPR (26.7\%). Table 4 also shows that the major source of vaccine for goat in experimental area is local bazar $(91.1 \%)$. The remaining portion $(8.9 \%)$ gets vaccine for goat from the livestock office. This indicates that there were gaps between the farmers and livestock office. Main source of used medicine for goat in experimental area was medicine shop (66.7\%). Some people can get medicine from hospital. This is lower in number (33.3\%).

\section{Rearing cost of goat}

From the experiment, it has been found that the average feed cost was 486 BDT, breeding cost was 86 BDT and average cost of housing and equipment was 1144 BDT, average cost of medicine was 390 BDT and vaccine was 48 BDT for 12 months (Table 5). It is also shown that the average rearing cost of 1 goat was 2154 BDT (Table 5).

\section{Return from goat rearing}

The return of goat rearing comes in two ways i.e., one from kid and another from milk. All newly born kids (whether male or female) were sold at the age of six month to one year and these benefits were added to the yearly income of the farmers. The value of kid varied from BDT 1500 to BDT 5450. Considering total income and total expenditure the net income was 2142 BDT.

\section{Livelihood improvement of farmers by goat rearing}

Livelihood of farmers was improved in the experimental area in relation to purchasing capacity, social status and increased employment through rearing of goat (Table 6).

Table 2. Educational and occupational status in experimental area

\begin{tabular}{lcc|lcc}
\hline \multicolumn{3}{c|}{ Educational status } & \multicolumn{3}{c}{ Occupational status } \\
\hline Category & Frequency & Percent & Category & Frequency & Percent \\
\hline Illiterate & 2 & 4.4 & Agriculture & 26 & 7 \\
Primary & 21 & 46.7 & Service & 12 & 15.6 \\
Below S.S.C & 16 & 35.6 & Business & & 26.7 \\
Degree pass & 6 & 13.3 & & 45 & 100.0 \\
\hline Total & 45 & 100.0 & Total & & \\
\hline
\end{tabular}




\section{Goat farming for poor farmers}

\section{Discussion}

\section{Socio-economic information of the farmers in Haluaghat Upazila}

Most of the goats in Bangladesh are reared by small farmers in rural areas. Most of the farmers in Haluaghat upazila had a minimum or no land for cultivation. Saadullah and Hossain (2000) found that more than $70 \%$ of the goats belong to the landless and small farmers. According to Kamaruddin (2002), about $76 \%$ of goat is reared by landless and small farmers.

It was found that the educational level of farmers was gradually increased day by day. Because now-a-days they come to know the importance of education and for this reason they try to send their children to school. The selected farmer families were engaged with various types of occupation. Agriculture was obviously the main occupation in the study area. Some farmers were observed to have subsidiary occupations such as business, service etc.

\section{Main feeds and major sources of feed for goat in experimental area}

Various types of feed ingredients were used in the study area for goat rearing. The most common ingredients were green grass, wheat bran and tree leaves. The farmers were mainly depended on green grasses and tree leaves because of their availability. Numerous works suggested that various tree leaves usually used as a scarcity feed or supplement feed for goat (Saadullah, 1989; Islam et. al., 1991; Alam and Akbar, 1989). Goats utilize tree leaves and shrubs efficiently and if fed adequately, it may accelerate their potential productivity (Amin and Alam, 1990).
The major sources of feed ingredients they provide to goats were own sources. It was mainly tree leaves or green grasses. Besides this, they had another sources of feeds i.e., roadside grasses. But, during the rainy season the availability of green grasses and roadside grasses became lower. At that time farmers had to purchase feed from other side and during this time feed cost were increased for goat rearing.

\section{Disease and health care of goats}

The goats were more susceptible to skin disease, because the farmers of experimental area have little or no knowledge about the causes of skin disease. This was due to lack of proper training of farmers on goat rearing. Nooruddin et. al. (1987) reported $26.8 \%$ prevalence of skin disease of Black Bengal goat in Mymensingh district. Another important disease was PPR, a highly infectious viral disease of goat that can occur any time (Balamurugan et. al., 2012). According to Nath et. al. (2014), the prevalence of PPR was highest in winter (13.38\%) and lowest in summer (08.93\%). They also found highest PPR outbreak in male $(28.52 \%)$ than in female $(13.04 \%)$ goats.

Most of the farmers did not use vaccine in the experimental area. But the farmers of Norail Union were much aware about the use of vaccine. They collected vaccines from the local market and/or from livestock office. Basically, farmers did not use medicine except chronic condition, because they do not have available sources of medicine. The main source of medicine for goat was medicine shops which were far away from their houses. They did not get enough facility from the livestock office; there were gap between the farmers and livestock office.

Table 3. Main feeds and major sources of feed for goat in experimental area

\begin{tabular}{lcc|lcc}
\hline & Main feed & & \multicolumn{3}{c}{ Major sources of feed } \\
\hline Category & Frequency & Percent & Category & Frequency & Percent \\
\hline Grass & 15 & 33.3 & Roadside & 15 & 33.3 \\
Wheat Bran & 16 & 35.6 & Own & 16 & 35.6 \\
Tree leaves & 14 & 31.1 & Purchase & 14 & 31.1 \\
\hline Total & 45 & 100.0 & Total & 45 & 100.0 \\
\hline
\end{tabular}

Table 4. Major disease of goat and sources of vaccine in experimental area

\begin{tabular}{lcc|lcc}
\hline \multicolumn{3}{c|}{ Major diseases of goat } & \multicolumn{3}{c}{ Sources of vaccines } \\
\hline Category & Frequency & Percent & Category & Frequency & Percent \\
Skin disease & 33 & 73.3 & Bazar & 41 & 91.1 \\
PPR & 12 & 26.7 & Livestock office & 4 & 8.9 \\
\hline Total & 45 & 100.0 & Total & 45 & 100.0 \\
\hline
\end{tabular}


Hossain et al. (2017) Bang. J. Anim. Sci. 46 (1): 29-34

\section{Rearing cost of goat}

To analyze the cost-return it is necessary to describe the feed cost, breeding cost and cost of housing and equipment for goat rearing. The average cost of housing and equipment (per year) was higher than the average feed and breeding cost per year. Available local feed resources are usually used as goat feed including Mulberry (Morus alba), Bananas (main stem), cassava hay (cassava sterm and leaves) and cassava roots in Vietnam (Nguyen and Nguyen, 2012). Farmers generally bred their goat from the neighbor's buck and they did not do any artificial insemination in goat rearing. For this reason the breeding cost was lower than another cost.

Table 5. Average cost for goat rearing per year

\begin{tabular}{lr}
\hline Category & Frequency (BDT) \\
\hline Average feed cost & 486 \\
Average breeding cost & 86 \\
Average cost of housing & 1144 \\
and equipment & 390 \\
Average cost of medicine & 48 \\
Average cost of vaccine & $\mathbf{2 1 5 4}$ \\
\hline Total
\end{tabular}

On the other hand, they purchased feed only during the scarcity period. The major cost of healthcare is medicinal cost. For medicine they were mostly dependent on the medicine shops located far from their house. For this reason, the average healthcare cost of goats was increased. During the rainy season, the occurrence of disease was spread-out due to lack of proper knowledge about the disease prevention and at that time the healthcare cost was increased. But, now-a-days various NGO's doing some handy jobs in aspect of preventing various livestock diseases by advising primary knowledge of disease prevention, providing veterinary services and giving trainings.

\section{Return from goats}

The main return from goat of experimental area was from kids. Goats are traditionally raised by the rural people mostly for cash income and this is especially true for Black Bengal goat (Rahman et. al., 1998). Generally, Black Bengal goats are poor milk producer having short lactation period. Farmers sold some milk in the markets, some were consumed by the family and in most cases the available quantity of goat milk were consumed by its kids. Saadullah (1995) reported that, goat milk contribute more than $28 \%$ of the total milk yield in the country. Total goat milk production in Asia as percentage of all milk is small and is about 3.6\% (FAO, 2010)

The net income was 2142 BDT which indicated that rearing of goat in the experimental area was profitable. Akter (2004) observed that per household annual total cost of production of Black Bengal goat was BDT 1651, while total income was BDT 2290 and net income was BDT 639.

\section{Livelihood improvement}

Livelihood of farmers in the experimental area was improved by goat rearing. Purchasing capacity of the selected farmers was increased. Food purchasing capacity increased 55 percent before the study period. Similarly, cloths purchasing capacity was increased by 21 percent. Health care was increased by 23 percent on an average of the farmer's family after 12 months. Educational status 13 percent, social dignity 25 percent and social acceptance 25 percent increased after 12 months. According to Hossain et. al., (2005), farmers cash income and saving increased through goat rearing, increased social status as income increased, increased ability of expenditure on healthcare, cloths and other consumables. So, it was clearly found that livelihood improvement were upgrading in the experimental area by goat rearing.

Table 6. Increase of livelihood activities

\begin{tabular}{lcccc}
\hline Category & Initial Value (BDT) & Final Value (BDT) & Frequency (\%) & Rank order \\
\hline Food & 585 & 1300 & 55 & $\mathbf{1}$ \\
Social status & 700 & 934 & 25 & $\mathbf{2}$ \\
Health care & 530 & 690 & 23 & $\mathbf{3}$ \\
Cloths & 470 & 588 & 21 & $\mathbf{4}$ \\
Education & 340 & 392 & 13 & $\mathbf{5}$ \\
House & 260 & 274 & 5 & $\mathbf{6}$ \\
\hline
\end{tabular}




\section{Goat farming for poor farmers}

\section{Summary and Conclusion}

The experiment was undertaken in different union of Haluaghat Upazila in Mymensingh district in Bangladesh with the objective- livelihood improvements through goat rearing. The value of kid varies from BDT 1500 to BDT 5450. Total net income was 2142 BDT. It was found that in terms of net income rearing of goat was the most suitable way to increase the socio-economic status of the farmers having very small capital.

\section{References}

Akter T (2004). Impact of goat farming on women development on some selected areas of Mymensingh districts. M. Sc. Thesis, Department of Agricultural Finance, Bangladesh Agricultural University, Mymensingh.

Alam N and MA Akbar (1989). A study on the effect of supplementation of mango (Mangifera indica) and Shaora (Streblus asper) leaves to the diet of indigenous goat. M. Sc. Dissertation. Department of Animal Science. Bangladesh Agricultural University.

Amin SM and MR Alam (1990). Utilization of native grass by goat. M. Sc. Dissertation. Department of Animal Science. Bangladesh Agricultural University.

Balamurugan V, P Saravanan, A Sen, KK Rajak, G Venkatesan, P Krishnamoorthy, V Bhanuprakash and RK Singh (2012). Prevalence of peste des petits ruminants among sheep and goats in India. Journal of Veterinary Science, 13(3): 279-285.

BBS (2007). Statistical Year Book of Bangladesh, Bangladesh Bureau of Statistics Ministry of Planning, Government of the People's Republic of Bangladesh.

BBS (2014). Statistical Year Book of Bangladesh, Bangladesh Bureau of Statistics Ministry of Planning, Government of the People's Republic of Bangladesh.

Hossain MM, TH Miah, RN Ali, RH Sarwer and M Ahmed (2005). Livelihood improvement through duck, chicken and goat rearing (Bengali booklet) DFID-LPP Project R8109, Department of Animal Science. Bangladesh Agricultural University.

FAO (Food and Agricultural Organization of the United Nations) (2009). Asian livestock monthly technical magazine of the FAO. Animal Production and Health Commission or Asian the pacific (APHGA). 5: 85 .
FAO (Food and Agriculture Organisation), 2010. FAO AGROSTAT, 53, FAO, Rome, Italy

Huq ME, MM Rahman and MAM Miah (1990). A. Study on the relationship between management practices followed by the goat raisers with some of their selected characteristics in a selected area of Satkhira upazila. Bangladesh Journal of Animal Sciences, Vol. 19 (1-2).

Islam M, MR Islam and MM Rahman (1991). Potential shrubs and tree fodder for small holder livestock production in Bangladesh, Asian Livestock, vol. 16(2).

Islam MR and Huque QME (2002). Proceedings of the workshop on poverty alleviation through goat production: National Program (27 April to 23 May, 2002), Bangladesh Livestock Research Institute, Savar, Dhaka.

Kamaruddin KM (2002). Goat production in Bangladesh present status and future prospect, Khamar, A monthly magazine on poultry, livestock and fisheries, July-August, 2002, Dhaka.

Nath TC, MJU Bhuiya, MA Mamun, T,Datta. SK Chowdhury, M Hossain and MS Alam (2014). Common infectious diseases of goats in Chittagong district of Bangladesh. International Journal of Scientific Research in Agricultural Sciences, 1(3), pp. 43-49.

Nguyen, MD and NA Nguyen (2012). E-Proceedings of the first Asia dairy goat conference. April 9 12, 2012. Corus Hotel Kuala Lumpur, Malaysia: 52-55.

Nooruddin M, MH Hoque, MA Barik and. SMN Islam, (1987). Prevalence of skin diseases in Black Bengal goats. Bangladesh Veterinarian, Vol.4 No.1-2 pp.5-9 ref 8 .

Rahman, MM, S Akter and MM Hossain (1998). The availability of livestock feeds and feeding practies followed by the farmers of some areas of Mymensingh district. Bangladesh Journal of Animal Science, 27(1-2): 119-126.

Saadullah M (1989). Availability and use of shrubs and tree fodder in Bangladesh, Proceedings of a workshop on shrubs and tree fodder for farm animals in Deupasar, Indonesia, 24-29 July, 1989, Editor, C. Devendra. 221-236.

Saadullah M (1995). Integrated farming for rural poor. Rural Poor Programme Task Force of BRDB/SIDA. Dhaka.

Saadullah M and Hossain MM (2000). Qualification of locally available feed resources and and feeding systems of animal in different regions of Bangladesh, Bangladesh Agricultural Research Council, Farmgate, Dhaka and Bangladesh Agricultural University, Mymensingh, pp-32. 